\title{
Are there autoantibodies reacting against citrullinated peptides derived from type I and type II collagens in patients with rheumatoid arthritis?
}

\author{
M-K Koivula, S Åman, A Karjalainen, M Hakala, J Risteli
}

Ann Rheum Dis 2005;64:1443-1450. doi: 10.1136/ard.2004.031211

See end of article for authors' affiliations a.r.

Correspondence to: Professor J Risteli, University of Oulu, PL $5000, \mathrm{Fl}-90014$ Oulun yliopisto, Finland; juha.risteli@oulu.fi

Accepted 21 March 2005

\begin{abstract}
Objectives: To assess the possible presence in patients with rheumatoid arthritis (RA) of autoantibodies recognising citrullinated peptides derived from type I and II collagens.

Methods: Firstly, the binding of four pairs of synthetic peptides (arginine-containing and artificially citrullinated forms) related to different regions of human type II collagen were tested with sera from 120 patients with RA and 81 controls. Secondly, two similar pairs of peptides related to the carboxy terminal telopeptides of the $\alpha 1$ and $\alpha 2$ chains of human type I collagen were tested.

Results: $42-53 \%$ of the RA sera showed increased binding of arginine peptides related to type II collagen. However, 12 RA sera bound the citrullinated form of the $\alpha 1$ (II) telopeptide more strongly than the corresponding arginine peptide. 20 RA sera bound the citrullinated carboxytelopeptide from the $\alpha 1$ chain of type I collagen ( $\alpha$ l (I) telopeptide) more strongly than the respective arginine peptide. The correlation between the autoantibodies to type I and II collagen telopeptides was $r_{s}=0.576, p<0.001$. Anti-cyclic citrullinated peptide (anti-CCP) assay was positive in 71/120 (59\%) patients with RA. An anti-CCP assay detects a different subgroup of antibodies than anti-telopeptide assays. However, both anti-telopeptide and anti-CCP antibodies were increased in patients with RA.

Conclusion: Some patients with RA were identified whose sera contained antibodies that specifically bound citrullinated peptides related to the carboxy terminal telopeptides of the $\alpha 1$ and $\alpha 2$ chains of type $I$ collagen and the $\alpha 1$ chains of type II collagen (sequences YYXA, FYXA, and YMXA, where X stands for citrulline).
\end{abstract}

these antibodies include an association of citrullination with apoptosis, the appearance of anti-CCP antibodies before the occurrence of clinical symptoms and their specificity for RA, and the suggested genetic risk factor that leads to increased citrullination associated with RA. ${ }^{10}$

There is no filaggrin in joints, which means that the autoantibodies reacting with this protein most probably only reflect an immunological cross reaction. ${ }^{11}$ Possible candidates for the original immunogen include citrullinated $\alpha$ and $\beta$ chains of fibrin in synovial tissue ${ }^{12}$ and the Sa antigen, identified as citrullinated vimentin. ${ }^{13}$ However, production of anti-citrullinated filaggrin antibodies precedes disease onset, which contradicts the simple hypothesis that citrullination or anti-citrullinated filaggrin antibodies, or both, are pathogenic on their own. ${ }^{11}$ For instance, deep destruction of cartilage and erosion of bone in periarticular tissue cannot be induced by these autoantibodies unless citrulline is present in some major extracellular matrix proteins, such as type I and II collagens.

It has long been assumed that autoimmunity against collagens might be involved in the pathogenesis of RA. However, the evidence is only circumstantial. In certain animal species-for example, rats, mice, rabbits, and monkeys, immunisation with type II collagen results in the development of polyarthritis resembling human RA. Type II collagen is post-translationally modified, and some of these modifications (for example, glycosylations of lysine at position 264) may be recognised by T cells. ${ }^{14}$ Anti-collagen

Abbreviations: $C C P$, cyclic citrullinated peptide; EIA, enzyme immunoassay; ELISA, enzyme linked immunosorbent assay; PADI, peptidylarginine deiminase; RA, rheumatoid arthritis 
Table 1 Characteristics of the patients with RA and controls studied

\begin{tabular}{lll}
\hline Characteristics & $\begin{array}{l}\text { Patients with RA } \\
\text { (n=120) }\end{array}$ & $\begin{array}{l}\text { Controls } \\
\text { ( } \mathbf{n = 8 1 )}\end{array}$ \\
\hline Women/men & $89 / 31$ & $58 / 23$ \\
$\begin{array}{l}\text { Age (years), mean (range) } \\
\text { Women's age (years), mean }\end{array}$ & $54(19-84)$ & $54(14-83)$ \\
(range) & $53(21-84)$ & $54(14-83)$ \\
Men's age (years), mean (range) & $57(19-81)$ & $55(21-74)$ \\
\hline
\end{tabular}

antibodies are formed not only against cartilage collagen but also against bone (type I collagen) and soft tissue collagens (for example, type III and V collagens). ${ }^{15}$ Antibodies against denatured collagens are more frequent and present in higher concentrations in RA sera than antibodies against native collagens. ${ }^{16}{ }^{17}$ These anti-collagen antibodies are by no means specific for RA, and their formation may be secondary to the destruction of connective tissues rather than a cause of the disease.
This study aimed at determining whether the autoantibodies present in RA have any association with possible citrullination of collagens. We used citrullinated and noncitrullinated synthetic peptides for sequences derived from human type I and II collagens as antigens and set up ELISAs for the antibodies that bound such peptides. Of the four peptides related to different parts of the type II collagen molecule, all arginine-containing and some citrullinated forms were more frequently bound by RA than by control sera. We also tested the carboxy terminal telopeptides of the two $\alpha$ chains of type I collagen and compared them with a similar peptide from type II collagen. The sequences of these three carboxy terminal telopeptides resemble each other, being YYXA, FYXA, and YMXA, respectively, where $\mathrm{X}$ is citrulline.

\section{SUBJECTS AND METHODS}

Patients and controls

The serum samples from 120 patients with RA were obtained from the division of rheumatology of Oulu University Hospital. The controls consisted of 81 sera from healthy
A

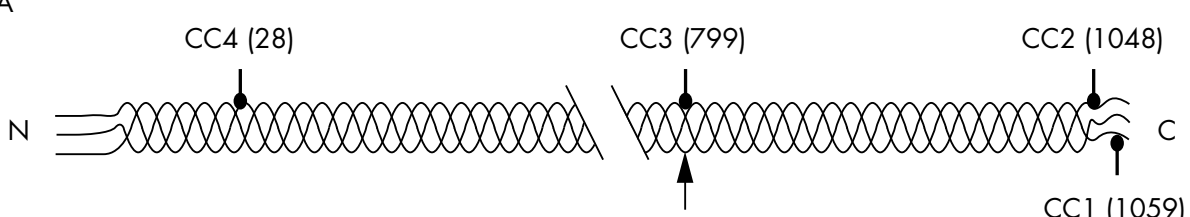

Collagenase cleavage site

-GPPGPQG LAGQRGE-

B

\begin{tabular}{|l|l|}
\hline$C C 1$ & EKGPDPLQYMXA \\
\hline$C C 2$ & SAFAGLGPXEKGPD \\
\hline$C C 3$ & LAGQXGIVGLP \\
\hline$C C 4$ & GPMGPXGPPGPA \\
\hline
\end{tabular}

$X=$ arginine/citrulline

C

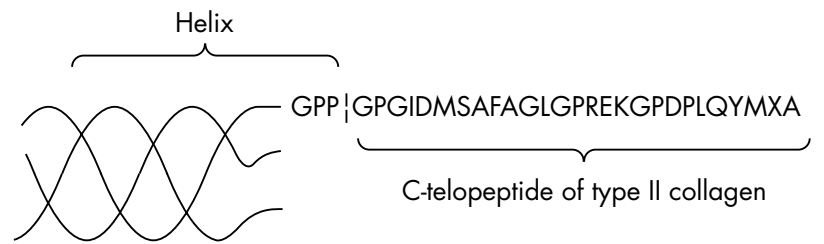

D

\begin{tabular}{|l|l|}
\hline C-telopeptide of $\alpha 1(I)$ & EKAHDGGRYYXA \\
\hline C-telopeptide of $\alpha 2(I)$ & YDFGYDGDFYXA \\
\hline
\end{tabular}

Figure 1 Sequences and localisations of the synthetic peptides used in the study. (A) Localisation of the peptides $\mathrm{CCl}-\mathrm{CC} 4$ in human type II collagen; the numbers in brackets refer to arginine residues. (B) Sequences of the peptides CC1-CC4. (C) Detailed structure of the $\mathrm{CCl}$ (1059) carboxy terminal telopeptide of type II collagen; the 12 carboxy terminal amino acids represent the peptide $\mathrm{CCl}$. (D) Sequences of the peptides related to the carboxy terminal telopeptides of the $\alpha 1$ and $\alpha 2$ chains of human type I collagen.

\footnotetext{
$X=$ arginine/citrulline
} 


\begin{tabular}{|c|c|c|c|}
\hline Peptides & $\begin{array}{l}\text { Controls } \\
\text { Mean (SD) } \\
\text { absorbance }\end{array}$ & $\begin{array}{l}\text { Controls over mean } \\
\pm 2 \mathrm{SD} \\
\text { (n) }\end{array}$ & $\begin{array}{l}\text { Patients with RA over } \\
\text { mean } \pm 2 S D \\
\text { (n) }\end{array}$ \\
\hline \multicolumn{4}{|l|}{ C-telopeptide of $\alpha 1$ (I) } \\
\hline Arginine peptide & $0.288(0.142)$ & $4 / 81$ & $6 / 120^{N S}$ \\
\hline Citrulline peptide & $0.314(0.117)$ & $2 / 81$ & $24 / 120^{* \star *}$ \\
\hline \multicolumn{4}{|l|}{ C-telopeptide of $\alpha 2($ (I) } \\
\hline Arginine peptide & $0.692(0.326)$ & $3 / 81$ & $22 / 120^{* \star *}$ \\
\hline Citrulline peptide & $0.763(0.356)$ & $3 / 81$ & $12 / 120^{* *}$ \\
\hline \multicolumn{4}{|c|}{$\mathrm{CCl}=\mathrm{C}$-telopeptide of $\alpha 1$ (II) } \\
\hline Arginine peptide & $0.181(0.077)$ & $2 / 81$ & $54 / 120^{* * *}$ \\
\hline Citrulline peptide & $0.155(0.065)$ & $2 / 81$ & $35 / 120^{* * *}$ \\
\hline \multicolumn{4}{|l|}{ CC2 } \\
\hline Arginine peptide & $0.162(0.053)$ & $3 / 81$ & $50 / 120^{* * *}$ \\
\hline Citrulline peptide & $0.135(0.054)$ & $1 / 81$ & $25 / 120^{* * *}$ \\
\hline \multicolumn{4}{|l|}{ CC3 } \\
\hline Arginine peptide & $0.182(0.0073)$ & $2 / 81$ & $63 / 120^{* * *}$ \\
\hline Citrulline peptide & $0.181(0.067)$ & $2 / 81$ & $32 / 120^{* * *}$ \\
\hline \multicolumn{4}{|l|}{ CC4 } \\
\hline Arginine peptide & $0.179(0.070)$ & $3 / 81$ & $60 / 120^{* * *}$ \\
\hline Citrulline peptide & $0.184(0.071)$ & $2 / 81$ & $22 / 120^{* * *}$ \\
\hline
\end{tabular}

people matched for age and sex (table 1). An experienced rheumatologist made the clinical diagnosis of RA, because the patients were in early stages of the disease. The study was approved by the ethical committee of Oulu University Hospital.

\section{Peptide antigens}

Six pairs of biotinylated peptides were synthesised by NeoMPS (Strasbourg, France). Figure 1 shows the sequences and locations of the chosen peptides in the primary structures of human type I and II collagens. One member of each pair contained the arginine predicted by the respective gene, whereas in the other member of the pair this was replaced by citrulline.

\section{ELISA assays}

The biotinylated peptides were coupled to streptavidin coated, 96 well assay plates (BioBind Assembly, Thermo Labsystems Oy, Vantaa, Finland) at a concentration of $10 \mu \mathrm{g} /$ well. The coupling was performed at room temperature, $\mathrm{pH}$ 7.5, for 2 hours. The streptavidin coated wells had been blocked by the manufacturer to prevent unspecific binding.

The sera to be tested were diluted in enzyme immunoassay (EIA) buffer $(20 \mathrm{mM}$ Tris- $\mathrm{HCl}, 150 \mathrm{mM} \mathrm{NaCl}, 0.1 \%$ bovine serum albumin, $0.05 \%$ Tween; $\mathrm{pH}$ 7.5) or assay buffer ( $10 \mathrm{mM}$ Tris- $\mathrm{HCl}, 350 \mathrm{mM} \mathrm{NaCl}, 1 \%$ bovine serum albumin, $1 \%$ (vol/vol) Triton X-100, 0.5\% (wt/vol) Na deoxycholate, $0.1 \%$ sodium dodecyl sulphate; $\mathrm{pH} 7.6$ ) supplemented with $1 \%$ rabbit serum ${ }^{7}$ and incubated in the well for 1 hour at room temperature ( $100 \mu \mathrm{l} /$ well). After washing (3-5 times with phosphate buffered saline/0.05\% (vol/vol) Tween-20), $100 \mu \mathrm{l}$ of antihuman IgG conjugated to peroxidase (product No 31412, Pierce, Rockford, IL, USA) diluted 1:7500 in EIA buffer was added. After incubation for 1 hour at room temperature, the plates were washed (3-5 times with phosphate buffered saline/Tween-20). The bound antibodies were detected with 3,3',5,5'-tetramethylbenzidine (SigmaAldrich, St Louis, MN, USA) as a substrate $(0.01 \mathrm{mg} / 100 \mu \mathrm{l}$ per well in $100 \mathrm{mM}$ sodium acetate trihydrate, $1.5 \mathrm{mM}$ citric acid monohydrate, $0.0015 \% \mathrm{H}_{2} \mathrm{O}_{2}$ ). After 30 minutes, the reaction was stopped by adding $100 \mu \mathrm{l}$ of $2 \mathrm{M}$ sulphuric acid/ well. The absorbances at a wavelength of $450 \mathrm{~nm}$ were read in a Victor ${ }^{2}$ instrument (Wallac, Turku, Finland) and the results calculated by Multicalc (Wallac). All sera were tested in duplicate. The coefficients of variation were generally $<10 \%$.

Anti-CCP-ELISA (the anti-CCP mark 2 assay) was used according to the procedure described by the manufacturer

\begin{tabular}{|c|c|c|c|c|c|}
\hline & Anti- $\alpha 1(1)$ & Anti- $\alpha$ (I) & $\begin{array}{l}\text { Anti- } \alpha 1(\text { III) = } \\
\text { Anti-CCP1 }\end{array}$ & Anti-CCP2 & Anti-CCP assay \\
\hline Anti- $\alpha 1(I)$ & & $\begin{array}{l}C=0.380^{* * *} \\
p<0.001\end{array}$ & $\begin{array}{l}C=0.286^{* * *} \\
p=0.001\end{array}$ & $\begin{array}{l}C=0.116 \\
p=0.202\end{array}$ & $\begin{array}{l}C=0.310^{* * *} \\
p<0.001\end{array}$ \\
\hline Anti- $\alpha 2(I)$ & $\begin{array}{l}C=0.380^{* * *} \\
p<0.001\end{array}$ & & $\begin{array}{l}C=0.398^{* * *} \\
p<0.001\end{array}$ & $\begin{array}{l}C=0.260^{* *} \\
p=0.003\end{array}$ & $\begin{array}{l}C=0.112 \\
p=0.217\end{array}$ \\
\hline Anti- $\alpha 1(I I)=$ anti-CCP1 & $\begin{array}{l}C=0.286^{* * *} \\
p=0.001\end{array}$ & $\begin{array}{l}C=0.398^{* * *} \\
p<0.001\end{array}$ & & $\begin{array}{l}C=0.171 \\
p=0.057\end{array}$ & $\begin{array}{l}C=0.215^{*} \\
p=0.016\end{array}$ \\
\hline Anti-CCP2 & $\begin{array}{l}C=0.116 \\
p=0.202\end{array}$ & $\begin{array}{l}C=0.260^{* *} \\
p=0.003\end{array}$ & $\begin{array}{l}C=0.171 \\
p=0.057\end{array}$ & & $\begin{array}{l}C=0.108 \\
p=0.236\end{array}$ \\
\hline Anti-CCP assay & $\begin{array}{l}C=0.310^{* * *} \\
p<0.001\end{array}$ & $\begin{array}{l}C=0.112 \\
p=0.217\end{array}$ & $\begin{array}{l}C=0.215^{*} \\
p=0.016\end{array}$ & $\begin{array}{l}C=0.108 \\
p=0.236\end{array}$ & \\
\hline
\end{tabular}




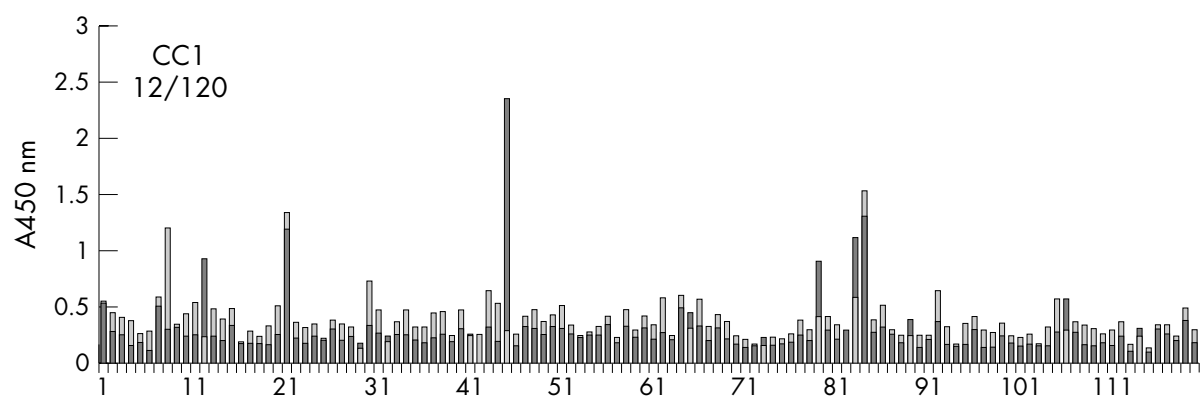

Figure 2 Binding of the peptides $\mathrm{CCl}$ to CC4 to the individual sera of 120 patients with RA. The numbers on the abscissa refer to the serum samples; normal peptides are shown as light grey columns and citrullinated peptides as dark grey columns. The ordinate shows the absorbance measured. For the peptides of CC3 and CC4, no serum bound more strongly to the citrullinated peptide than to the normal peptide. For the CC2 peptide two cases and for the CCl peptide 12 cases of preferential binding to the citrullinated peptide form

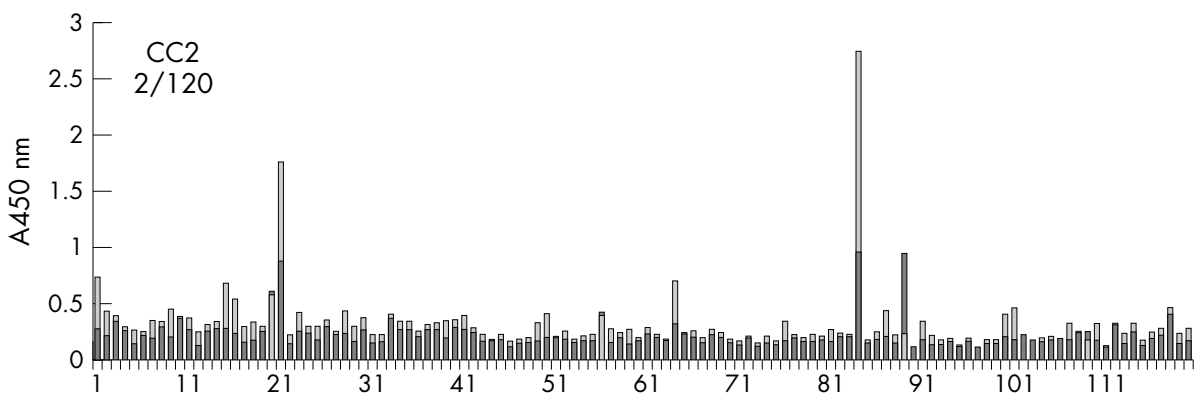
were seen.
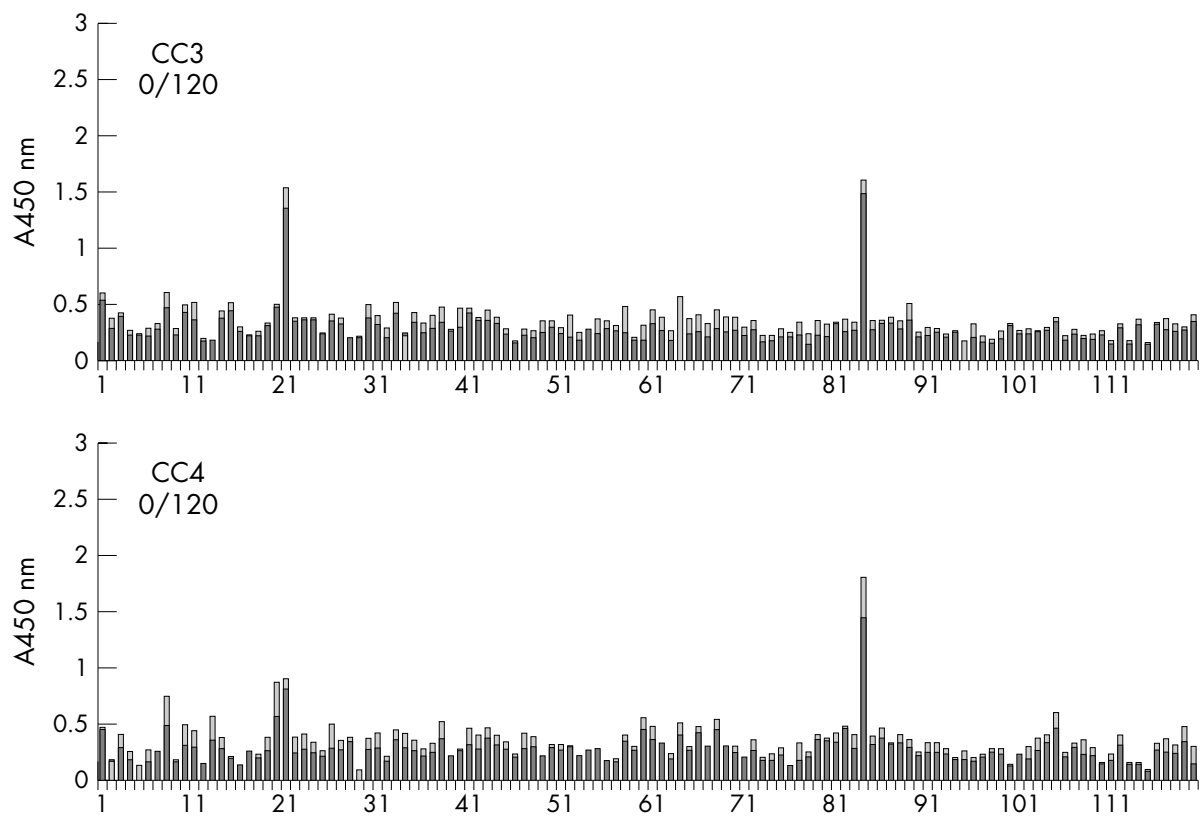

(Euro-Diagnostica, Malmö, Sweden). All sera, calibrators, and controls were measured in duplicate, and the results were averaged.

\section{Competition assay}

To evaluate antibody specificity we tested both anti-type I and II telopeptide assays and an anti-CCP mark 2 assay kit. Patients' sera were diluted in assay buffer to such antibody dilutions that in each assay the initial binding could be noticeably inhibited by different peptides. Serial dilutions of competitive peptides (arginine and citrullinated forms of Ctelopeptide of the $\alpha \mathrm{l}(\mathrm{I})$ and $\alpha \mathrm{l}$ (II) collagen antigens) were added (see fig 5 ). In the telopeptide assays, the peptide that was coupled to the plate was also used as a positive control. For the anti-CCP assay, no such control was used. The extent of competition was plotted as percentage inhibition against the soluble peptide concentration. The signal (wavelength of $450 \mathrm{~nm}$ ) obtained with human serum only (initial binding) was defined as $0 \%$ inhibition, and the signal of the blank (no serum) was defined as $100 \%$ inhibition.

\section{Calculations}

The absorbance results of each collagen peptide pair were compared between the patients with RA and controls (table 2). After that, the variance of the differences between the citrulline and the respective arginine peptides in the control samples was calculated for each peptide pair. On the basis of these variances, those patients with RA samples were identified for whom this difference exceeded the mean $\pm 2 \mathrm{SD}$ of the controls (see fig 4). The data were recorded and analysed on a microcomputer using the SPSS statistical software. Correlations were expressed as Spearman's rank correlation coefficient.

We compared the positive/negative results of anti-CCP and our anti-telopeptide assays in patients with RA by cross tabulation, using $2 \times 2$ contingency tables tested on the 


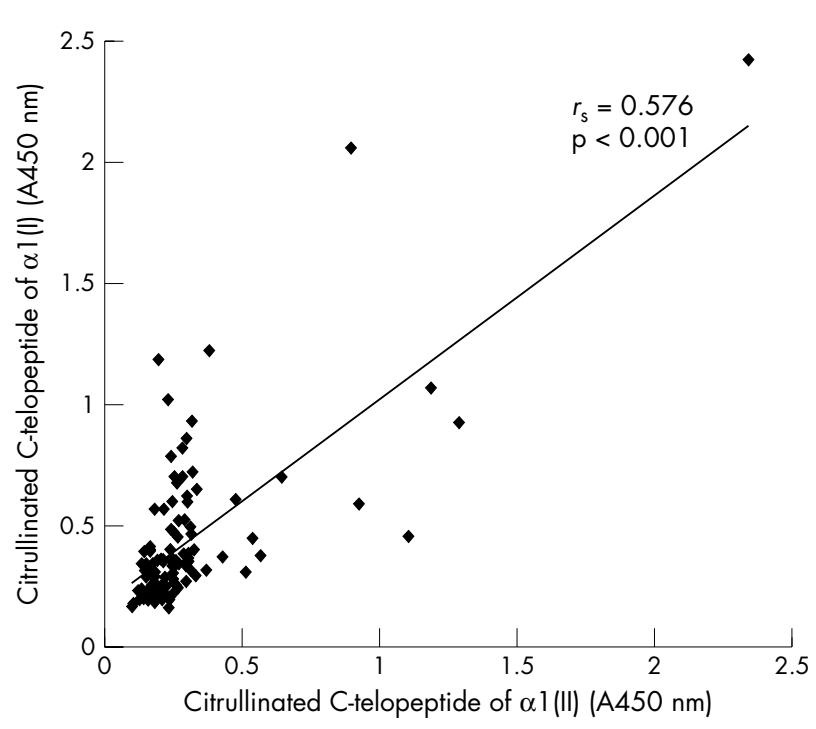

Figure 3 Correlation between the bindings (absorbance units) of the carboxy terminal telopeptides of the $\alpha$ l chains of type I and II collagens to the sera from patients with RA.

contingency coefficient ( $C$, which is always $0 \leqslant C<1$ ). In cross tabulation (table 3 ) the results are categorised as positives and negatives (positive anti-CCP $(\geqslant 25 \mathrm{U} / \mathrm{ml})$ and negative $(<25 \mathrm{U} / \mathrm{ml}$ ), positive $\alpha \mathrm{l}$ (I) (differences $\geqslant 0.175)$ and negative (differences $<0.175$ ), positive $\alpha 2(\mathrm{I})$ (differences $\geqslant 0.574$ ) and negative (differences $<0.574$ ), positive $\alpha \mathrm{l}(\mathrm{II})$ (differences $\geqslant 0.037$ ) and negative (differences $<0.037$ ), and positive
CCP2 (differences $\geqslant 0.032$ ) and negative (differences $<0.032)$ ).

\section{RESULTS}

Firstly, we tested the assay buffers, because we had initially found that the binding of antibodies from control sera in the buffer normally used in EIA is considerable for both arginine and citrulline peptides. When the assay buffer ${ }^{7}$ was used, which contains Triton, Na deoxycholate, and sodium dodecyl sulphate, the overall binding of antibodies decreased in all peptide pairs (not shown). The specific binding of citrullinated peptides, compared with arginine peptides and particularly for $\mathrm{CCl}$, was even better in the assay than in the EIA buffer. Accordingly, in all the remaining experiments, all samples were diluted in assay buffer at a concentration of 1:100.

When single peptides were analysed directly, $42-53 \%$ of the patients with RA showed increased binding of the peptides derived from type II collagen (table 2). However, in many of these patients citrullinated peptides (CC1-CC4) tended to be bound to a lesser extent than arginine peptides (table 2, fig 2). The binding of peptides related to the carboxy terminal telopeptide of type I collagen was also increased in the patients with RA, but not to the same extent as for type II collagen.

When each peptide pair was being tested, the means (absorbance value of citrullinated peptide minus that of arginine peptide) and variances of the differences of the control samples were -0.026 (SD 0.032) for CCl, -0.027 (0.029) for CC2, $-0.001(0.026)$ for CC3, and $+0.005(0.020)$ for CC4. There was no specific binding to the citrullinated forms of the CC3 and CC4 peptides of the RA sera (fig 2).

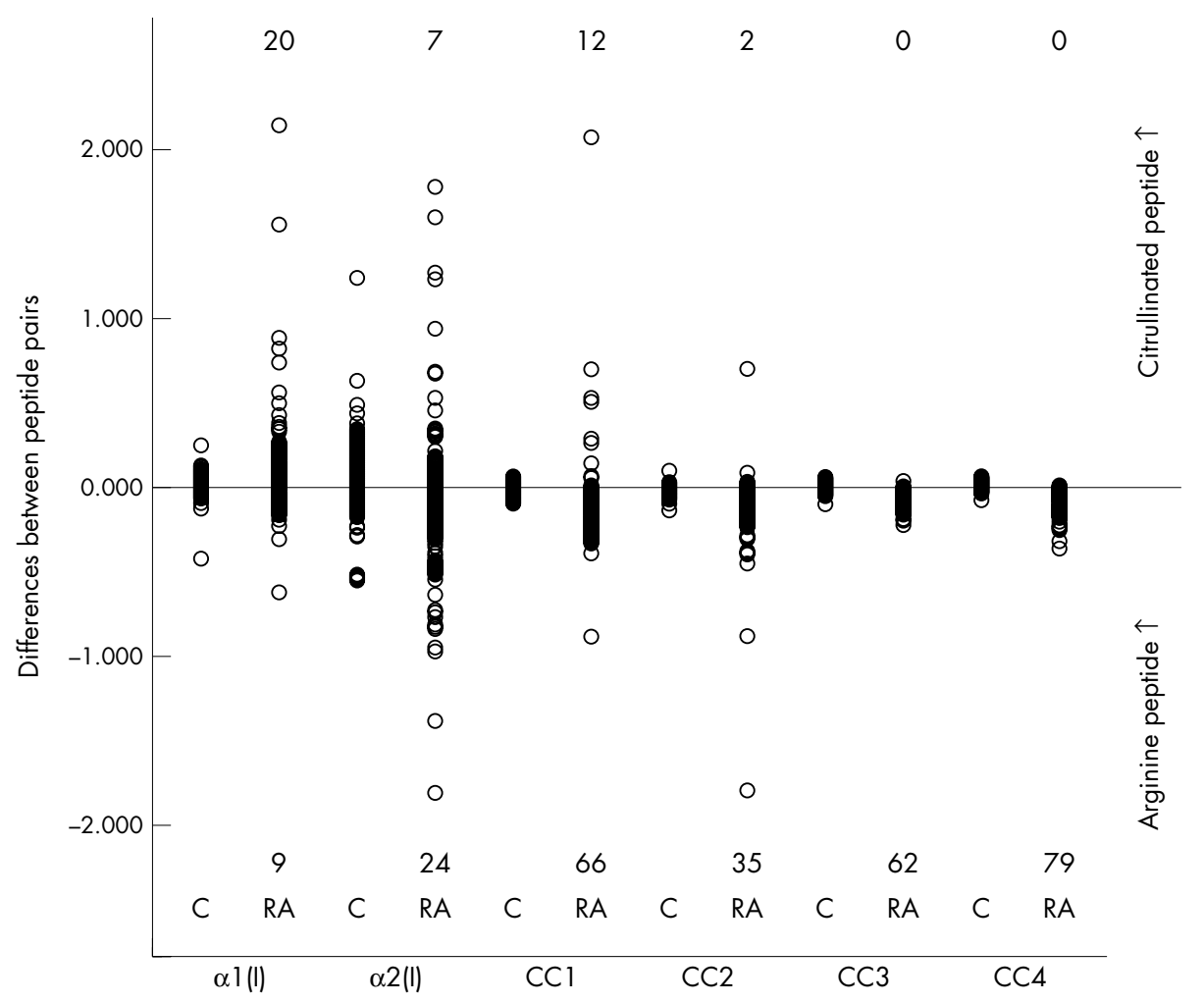

Figure 4 Differences in absorbance between the corresponding citrulline and arginine peptides in the patients with RA and controls for all peptide pairs tested. $C=$ controls, RA = patients with rheumatoid arthritis, each circle represents one serum sample. The circles in the upper part indicate the sera that bind citrullinated peptide more strongly than arginine peptide and vice versa for those in the lower part. The figures in the upper and lower parts indicate the numbers of the cases with preferential binding to either citrullinated or arginine peptide, respectively (exceeding $\pm 2 S D$ of the differences of control sera). 


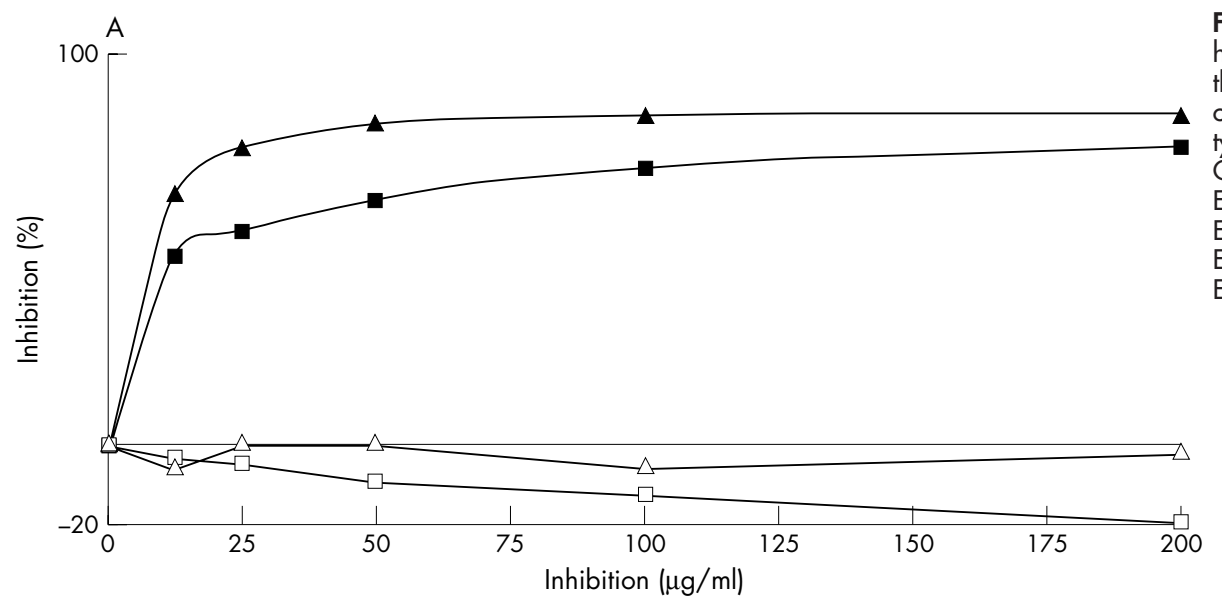

Figure 5 Competition assays. One human serum sample was tested in three different ELISAs: anti-

carboxytelopeptides of the $\alpha 1$ chain of type I (A) and II collagens (B) and antiCCP assays (C). The inhibitors were EKAHDGGRYYRA (open triangles), EKAHDGGRYYXA (closed triangles), EKGPDPLQYMRA (open squares), and EKGPDPLQYMXA (closed squares).
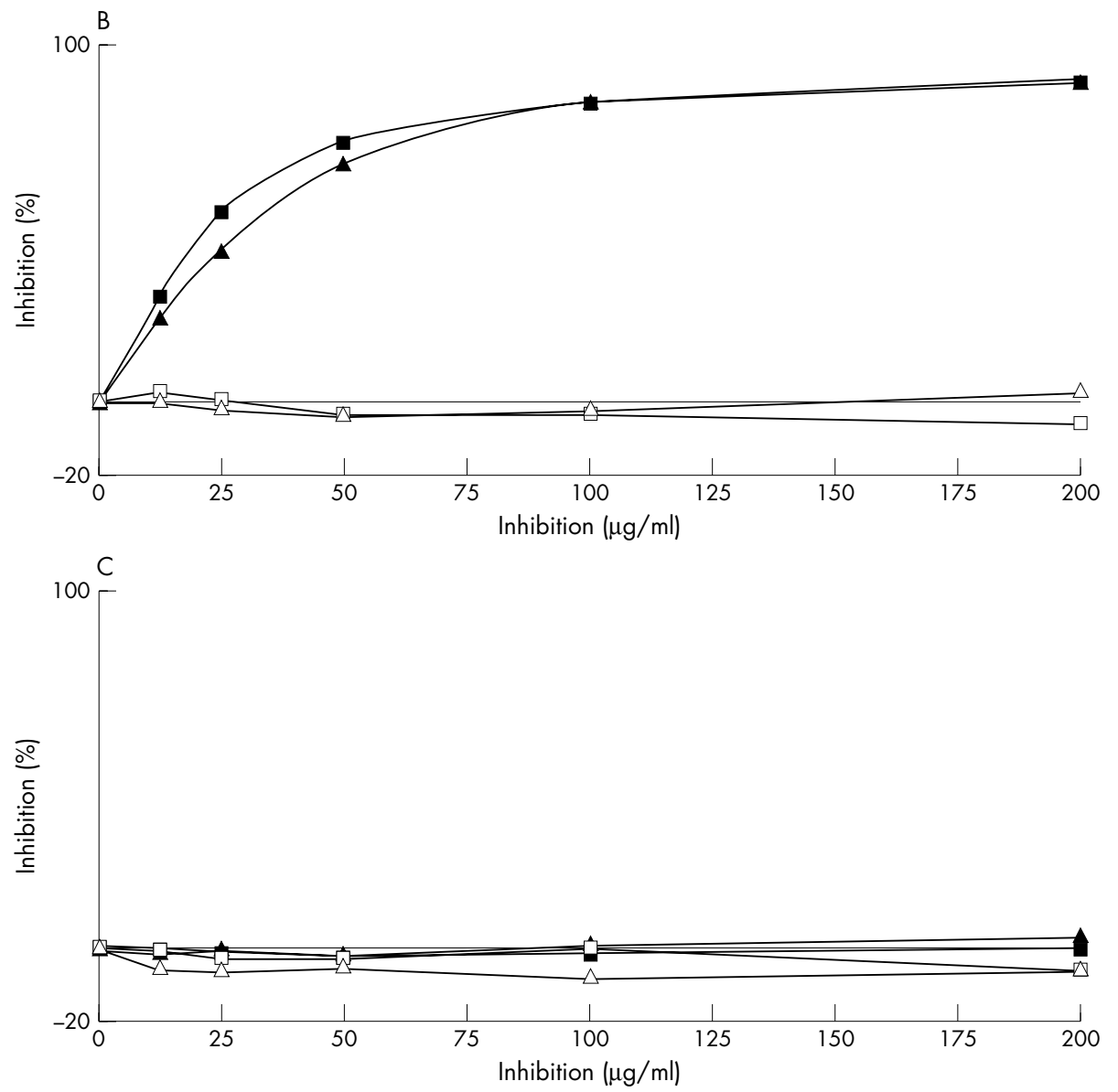

However, peptide CC2 and particularly peptide CC1 in the patients with RA showed differences, because two sera in the peptide CC2 group and 12 sera in the peptide CC1 group bound more citrullinated peptide than normal peptide (fig 2). For the $\alpha \mathrm{l}$ chain of type I collagen, the means (absorbance value of citrullinated peptide minus that of arginine peptide) and variances of the differences of the control samples were around $+0.026(0.074)$. There was a highly significant correlation between the binding of the telopeptide parts related to the $\alpha$ l chains of type I and II collagens in the sera of the patients with RA $\left(r_{\mathrm{s}}=0.576\right.$, $\mathrm{p}<0.001$, fig 3). With the C-telopeptide of the $\alpha 2$ chain from type I collagen, the means and variances of the differences between the control samples were +0.071 $(0.252)$. In this case the mean binding and variance were considerably higher (two- to fivefold) than those of the other peptides. However, there was also more binding in the RA sera than in the control sera.

Figure 4 summarises the overall results of peptide binding in the control and RA sera. The numbers of cases with more binding of citrullinated than respective arginine peptides (upper part of the figure) and vice versa (lower part of the figure) are indicated. In particular, there was increased binding of the citrullinated form of the carboxy terminal telopeptide of the $\alpha \mathrm{l}$ chains of type I collagen. Also, in the case of the carboxy terminal telopeptide of the $\alpha \mathrm{l}$ chain of type II collagen, some sera showed increased binding of the citrullinated forms. However, in the case of the $\alpha 2$ chain of type I collagen, there was no difference between the control and RA sera. 
The anti-CCP assay was positive in 71/120 (59\%) RA sera However, there was no correlation between the concentrations of autoantibodies against collagen telopeptides and those against CCP. We tested the specificity of the autoantibodies by analysing serum samples in anti-CCP assay and anti- $\alpha \mathrm{l}(\mathrm{I})$ and anti- $\alpha \mathrm{l}(\mathrm{II})$ assays and by inhibiting the binding in each case with all normal and citrullinated antigens. Soluble citrullinated telopeptide antigens inhibited the binding in both anti-type I and type II telopeptide assays (figs $5 \mathrm{~A}$ and $\mathrm{B}$ ). Thus, it seems that the same antibody species are involved in the binding of both collagen related peptides. However, the binding of CCP cannot be inhibited by collagen peptides (fig 5C). Although the specificities of autoantibodies are clearly different, anti-CCP and anti- $\alpha \mathrm{l}(\mathrm{I})$ and anti- $\alpha \mathrm{l}(\mathrm{II})$ collagen behave quite similarly in $2 \times 2$ contingency analysis (table 3 ). This indicates that nearly all the patients who have anti-telopeptide antibodies are also positive in an anti-CCP assay.

\section{DISCUSSION}

RA-specific antibodies can be detected by using either in vitro enzymatically citrullinated proteins or synthetic citrullinated peptide(s) as antigen. ${ }^{18}$ Here, we used the latter approach, because we wanted to study both helical and telopeptide domains. Previously, anti-collagen antibodies have been detected using a soluble collagen antigen, called atelocollagen, which was made soluble by pepsin treatment. However, this digestion removes the intermolecular cross links, including those located at the carboxy terminus. For this reason, we used the synthetic peptide approach, because it is not possible to study cross linked telopeptides with authentic collagens.

The pro- $\alpha$ l chain of type II procollagen contains 72 arginine residues, while the number of arginines in the corresponding collagen chain is 55. From this abundance of potential citrullination sites, we selected four peptides and had both their normal and artificially citrullinated forms synthesised (fig 1). The peptides were chosen to contain the first arginine (CC4, position 28) from the amino terminus of collagen itself, the first arginine after the collagenase cleavage site (CC3, 799) and the last and last but one arginines from the carboxy terminus (CC1, 1059 and CC2, 1048). Two of the peptide pairs (CC3 and CC4) are from the helical region of type II collagen, whereas the CCl peptide occurs at the non-helical end of the collagen molecule. We found that the CCl peptide and, to a lesser extent, the CC2 peptide, specifically bind autoantibodies against citrullinated proteins. These results suggest that the arginine near the carboxy terminal end might be susceptible to the action of PADI enzymes, an assumption which is also supported by the studies performed by Nomura. ${ }^{19}$

The pro- $\alpha 1$ and pro- $\alpha 2$ chains of type I procollagen contain 71 and 72 arginine residues, respectively, while the corresponding numbers in the collagen chains are 55 and 57 . We tested only the carboxy terminus of the two $\alpha$ chains of type I collagen, because the arginine-containing sequences at the carboxy terminal ends of type I (YYRA or FYRA) and type II (YMRA) collagens are quite similar. Our results indicate (fig 5) that the same or similar antibodies react with both cartilage and bone collagens, provided that there are citrullinated forms at the carboxy terminus.

In this study we were also able to show that $42-53 \%$ of patients with RA have autoantibodies against normal arginine-containing peptides derived from type II collagen. Previously, such autoantibodies have mainly been tested by using collagen preparations rendered soluble by pepsin digestion. ${ }^{16}{ }^{17}$ However, this protease removes the carboxy terminal telopeptides of collagens, as described above. When part of the resulting collagen preparations were denatured with heat, it was possible to compare antibody binding to native and denatured collagens. Many of the previously identified autoantibodies to type II collagen detected denatured peptides, ${ }^{16}{ }^{17}$ because these epitopes were hidden inside the collagen triple helix and not exposed on the surface of the molecule, if the collagen was in native conformation. The binding to the arginine peptides containing CC3 and CC4, identified in the present study (fig 2), obviously represents such autoantibodies. The specific citrullinated collagen sequences found in this study (YYRA and YMRA) would be quite similar in both native and denatured conformations, because carboxytelopeptides do not have a helical structure. However, the $\alpha 2$ chain of type I collagen might also be involved in this binding because of the similar sequence (FYRA), but in the fine structure of type I collagen this $\alpha 2$ telopeptide is shorter and probably hidden by two $\alpha \mathrm{l}$ chains. ${ }^{20}$

These experiments were performed with an ELISA, but we have also used an automatic immunoassay instrument, in which the serum is bound by biotinylated peptides in magnetic particles and detected by chemiluminescence. This format yielded more than twice the number of positive results in, for example, the anti-telopeptides of $\alpha \mathrm{l}(\mathrm{I})$ assay in the same patients with RA, indicating that the assay format is also important (results not shown here). However, the above ELISA method is suitable for visualising the existence and nature of these antibodies. The binding of antibodies against biotinylated citrullinated telopeptides can be inhibited by a similar non-biotinylated peptide in solution (fig 5), which is often not possible with autoantibodies, which bind both arginine and citrullinated peptides in denatured conformation.

It emerged that those patients who have autoantibodies against collagen telopeptides also have positive reactions on anti-CCP assay (table 3). We do not know what immunogen is involved when these autoantibodies are formed against citrullinated proteins. It may result from apoptosis because, both in filaggrin and in vimentin, citrullination occurs in proteins that are close to the end of their existence. ${ }^{21}$ This would mean that in patients with RA such antibodies against citrullinated proteins are produced, because such immunological phenomena are common in this disease. This anti-CCP antibody may precede disease onset by several years, which contradicts the simple hypothesis that citrullination or anticitrullinated peptide antibodies, or both, are pathogenic on their own. ${ }^{11}$

We have found a subset of autoantibodies that could bind collagens. There is no danger if there is no citrullination of collagens. However, if these previously innocent antibodies react with extracellular matrix components, such as type I and type II collagens, they could be harmful. These autoantibodies may be responsible for the destruction of both cartilage and periarticular bone, if the last carboxy terminal arginine is modified to citrulline by the PADIs. However, we have not yet studied the presence of citrullination in authentic type I and II collagens, and the hypothesis about such a presence is interesting but not yet proved. Nevertheless, anti-CCP antibodies can discriminate accurately between erosive and non-erosive $\mathrm{RA},{ }^{22}$ indicating that at least some of these autoantibodies may have a role in joint damage.

\section{ACKNOWLEDGEMENTS}

We thank Ms Liisa Kaarela and Ms Sanna Kortsalo for expert technical assistance. We also thank Kimmo Aho, MD, PhD, and Leila Risteli, MD, PhD, for critical comments on the manuscript.

Authors' affiliations
M-K Koivula, Department of Clinical Chemistry, University of Oulu,
Oulu, Finland

\section{Authors affiliations}

Oulu, Finland 
S Åman, A Karjalainen, Division of Rheumatology, Department of Internal Medicine, University of Oulu, Oulu, Finland

M Hakala, Rheumatism Foundation Hospital, Heinola, Finland J Risteli, Department of Clinical Chemistry, University of Oulu and Kuopio, Oulu and Kuopio, Finland

\section{REFERENCES}

1 Nienhuis RL, Mandema E. A new serum factor in patients with rheumatoid arthritis, the antiperinuclear factor. Ann Rheum Dis 1964;23:302-5.

2 Young B, Mallya RK, Leslie RD, Clark CJ, Hamblin TJ. Antikeratin antibodies in rheumatoid arthritis. BMJ 1979;ii:97-9.

3 Schellekens GA, de Jong BA, van den Hoogen FH, van de Putte LB, van Venrooii WJ. Citrulline is an essential constituent of antigenic determinants recognised by rheumatoid arthritis specific autoantibodies. J Clin Invest 1998;101:273-81.

4 Girbal-Neuhauser E, Durieux JJ, Arnaud M, Dalbon P, Sebbag M, Vincent C, et al. The epitopes targeted by the rheumatoid arthritis associated antifilaggrin autoantibodies are post-translationally generated on various sites of (pro)filaggrin by deimination of arginine residues. J Immunol 1999; 162:585-94.

5 Arnett FC, Edworthy SM, Bloch DA, McShane DJ, Fries JF, Cooper NS, et al The American Rheumatism Association 1987 revised criteria for the classification of rheumatoid arthritis. Arthritis Rheum 1988;31:315-24.

6 van Boekel MA, Vossenaar ER, van den Hoogen F, van Venrooij WJ. Autoantibody systems in rheumatoid arthritis: specificity, sensitivity and diagnostic value. Arthritis Res 2002;4:87-93.

7 Schellekens GA, Visser H, de Jong BA, van den Hoogen FH, Hazes JM, Breedveld FC, et al. The diagnostic properties of rheumatoid arthritis antibodies recognizing a cyclic citrullinated peptide. Arthritis Rheum 2000;43:155-63

8 Rantapää-Dahlqvist S, de Jong BA, Berglin E, Hallmans G, Wadell G, Stenlund $\mathrm{H}$, et al. Antibodies against cyclic citrullinated peptide and $\lg A$ rheumatoid factor predict the development of rheumatoid arthritis. Arthritis Rheum 2003:48:2741-9.

9 Nielen MMJ, van Schaardenburg D, Reesink HW, van de Stadt RJ, van der Horst-Bruinsma IE, de Koning MHMT, et al. Specific autoantibodies precede the symptoms of rheumatoid arthritis: a study of serial measurements in blood donors. Arthritis Rheum 2004;50:380-6.
10 van Gaalen FA, Linn-Rasker SP, van Venrooij WJ, de Jong BA, Breedveld FC, Verweij CL, et al. Autoantibodies to cyclic citrullinated peptides predict progression to rheumatoid arthritis in patients with undifferentiated arthritis: a prospective cohort study. Arthritis Rheum 2004;50:709-15.

11 Yamada R, Suzuki A, Chang X, Yamamoto K. Citrullinated proteins in rheumatoid arthritis. Front Biosci 2005; 10:54-64.

12 Masson-Bessiere C, Sebbag M, Girbal-Neuhauser E, Nogueira L, Vincent C, Senshu $\mathrm{T}$, et al. The major synovial targets of the rheumatoid arthritis-specific antifilaggrin autoantibodies are deiminated forms of the $\alpha$ - and $\beta$-chains of fibrin. J Immunol 2001; 166:4177-84.

13 Vossenaar ER, Despres N, Lapointe E, van der Heijden A, Lora M, Senshu T, et al. Rheumatoid arthritis specific anti-SA antibodies target citrullinated vimentin. Arthritis Res Ther 2004;6:R142-50.

14 Holmdahl R, Bockermann R, Bäcklund J, Yamada H. The molecular pathogenesis of collagen-induced arthritis in mice - a model for rheumatoid arthritis. Ageing Res Rev 2002;1:135-47.

15 Stuart JM, Huffstutter EH, Townes AS, Kang AH. Incidence and specificity of antibodies to types I, II, III, IV and V collagen in rheumatoid arthritis and other rheumatic diseases as measured by ${ }^{125}$-radioimmunoassay. Arthritis Rheum 1983;26:832-40

16 Claque RB, Shaw MJ, Holt P. Incidence and correlation between serum IgG and $\lg M$ antibodies to native type II collagen in patients with chronic inflammatory arthritis. Ann Rheum Dis 1981;40:6-10.

17 Rowley M, Tait B, Mackay IR, Cunninghan T, Phillips B. Collagen antibodies in rheumatoid arthritis. Significance of antibodies to denatured collagen and their association with HLA-DR4. Arthritis Rheum 1986;29:174-84.

18 Nijenhuis S, Zendman AJ, Vossenaar ER, Pruijn GJ, van Venrooii WJ. Autoantibodies to citrullinated proteins in rheumatoid arthritis: clinical performance and biochemical aspects of an RA-specific marker. Clin Chem Acta 2004;350:17-34.

19 Nomura K. Specificity and mode of action of the muscle-type protein-arginine deiminase. Arch Biochem Biophys 1992;293:362-9.

20 Orgel JP, Wess TJ, Miller A. The in situ conformation and axial location of the intermolecular cross-linked non-helical telopeptides of type I collagen. Structure Fold Des 2000;8:137-42.

21 van Venrooii WJ, Pruijn G. Citrullination: a small change for a protein with great consequences for rheumatoid arthritis. Arthritis Res 2000;2:249-51

22 Visser H, le Cessie S, Vos K, Breedveld FC, Hazes JM. How to diagnose rheumatoid arthritis early: a prediction model for persistent (erosive) arthritis. Arthritis Rheum, 2002;46:357-65. 